\title{
A Rare Cause of Acute Paraplegia: Aneurysmal Bone Cyst
}

\author{
Akut Paraplejinin Nadir Bir Nedeni: Anevrizmal Kemik Kisti
}

\author{
(D) Gülcan Öztürk, (1) Ayşe Duygu Şilte Karamanlıoğlu, (1) Pınar Akpınar, (1) Feyza Ünlü Özkan, (D) ilknur Aktaş
}

Fatih Sultan Mehmet Training and Research Hospital, Clinic of Physical Medicine and Rehabilitation, İstanbul, Turkey

\section{Abstract}

Aneurysmal bone cyst of the spine can rarely cause acute paraplegia in young patients. A 30-year-old male patient presented to our physical medicine and rehabilitation outpatient clinic with back pain and bilateral lower extremity weakness for 2 weeks. The patient had no history of trauma. In magnetic resonance imaging, the cystic lesions were determined which destructive, contain internal septations and have multiple fluid-fluid levels at the T5-T6 level. The aneurysmal bone cyst was shown by histopathology. Complete resection to the cystic lesion and posterior segmental instrumentation at T2-T7 level were performed. In the control examination performed 6 months later, lower extremity muscle strength was complete and no recurrence was detected.

Keywords: Acute paraplegia, aneurysmal bone cyst, young patient

\section{Öz}

Genç hastalarda omurga yerleşimli anevrizmal kemik kistleri nadiren akut paraplejiye neden olabilirler. Otuz yaşında, erkek hasta 2 haftadır mevcut olan sırt ağrısı ve her iki bacakta güçsüzlük şikayeti ile Fiziksel Tıp ve Rehabilitasyon Polikliniği'mize başvurdu. Hastanın travma öyküsü yoktu. Dorsal magnetik rezonans görüntülemede T5-6 seviyesinde destrüktif, internal septasyonlar içeren, multipl sIVI-SIVI seviyesi olan kistik lezyonlar tespit edildi. Histopatoloji ile anevrizmal kemik kisti gösterildi. Kistik lezyona komplet rezeksiyon ve T2-T7 seviyesinde posterior segmental enstrümentasyon uygulandı. Altı ay sonra yapılan kontrol muayenesinde alt ekstremite kas gücü tamdı, rekurrens tespit edilmedi. Anahtar kelimeler: Akut parapleji, anevrizmal kemik kisti, genç hasta

\section{Introduction}

Aneurysmal bone cyst $(A B C)$ is vascular, non-neoplastic tumor like lesion. $A B C$ consist of blood filled osteolytic cystic cavities separated by connective tissue septa containing fibroblast, osteoclast and reactive woven bone (1). Although $A B C$ is benign lesion, it is extensive and destructive that can result in pathological compression fracture, spinal cord compression and spinal instability (2). ABC consist of $1-1.4 \%$ of all primary bone tumors $(3,4)$. The spine is involved in $15 \%$ of them (5). Lumbar spine is most affected spine localization, cervical spine, thoracic spine, sacral spine also can be affected, respectively. We report a rare case of $A B C$ with acute paraplegia with thoracic involvement that was successfully treated surgical decompression and stabilisation (1).

\section{Case Report}

A 30 year old young man admitted to the 50023 outpatient clinic with two weeks progressive back pain increasing with lying position, sudden onset paraplegia and decreased sensation in bilateral lower extremities. Before a week the patient admitted to emergency department and intramuscular (IM) myorelaxant and non-steroid anti-inflammatory drug injection was inserted with dorsal muscular strain diagnose. The patient stated that after IM injection lower extremity weakness had been started. On physical examination there was T4-6 spinous process tenderness. Neurological examination revealed right lower extremity proximal 4/5, distal 3/5 and left both upper and lower extremity $3 / 5$ muscle strength. There was decreased sensation in bilateral lower extremities. Deep tendon reflexes were bilateral hyperactive in lower extremity. His bilateral Babinski sign was positive. The bowel and bladder habits were normal. There was no history of trauma. $X$ ray of the spine was normal. The magnetic resonance imaging (MRI) revealed expansile mass that have characteristics of $A B C$ with internal septationand multiple fluid-fluid level at T5-6 level. The lesion involved T5-6 vertebra with bilaminar destruction and severe spinal cord compression (Figure1). Neurosurgery consultant was offered. Urgent spinal cord decompression and stabilization

Address for Correspondence/Yazıșma Adresi: Gülcan Öztürk MD, Fatih Sultan Mehmet Training and Research Hospital, Clinic of Physical Medicine and Rehabilitation, İstanbul, Turkey Phone: +90 5052851393 E-mail: drgul_can@hotmail.com ORCID ID: orcid.org/0000-0002-9464-301X Received/Geliş Tarihi: 10.05.2019 Accepted/Kabul Tarihi: 12.02.2019 
were deemed necessary to prevent further neurological deterioration and to optimize clinical outcome. He underwent left transpedicular approach and complete excision of the lesion followed by posterior segmental instrumentation at the T2-T7 levels (Figure 2). Embolisation has not been applied because of thoracic aortography showed no abnormality except minimal opacification in left T5 intercostal artery. The excised lesion had consisted of cystic trabeculations with a dark red fleshy appearance with moderate vascularity. Final histopathology confirmed the diagnosis of $A B C$. Post operatively, he had complete relief of pain. The patient had dramatic improvement in her bilateral lower extremities strength with $5 / 5$ muscle strength on the control examination after six months.

\section{Discussion}

$A B C$ is a rare, non-neoplastic, expansile, highly vascular osseous lesion. $A B C$ consist of blood filled spaces separated by connective tissue septa containing fibroblast, osteoclast and reactive woven bone (1). ABC was first defined by Jaffe and Lichtenstein
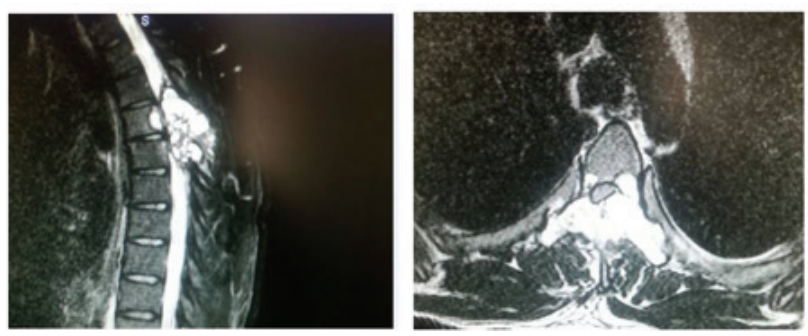

Figure 1. T2-weighted sagittalandaxial magnetic resonance imaging T2-weighted image of the thoracic spine demonstrating alyticlesion involving predominantly the posterior elements of the T5 and T6 vertebrae

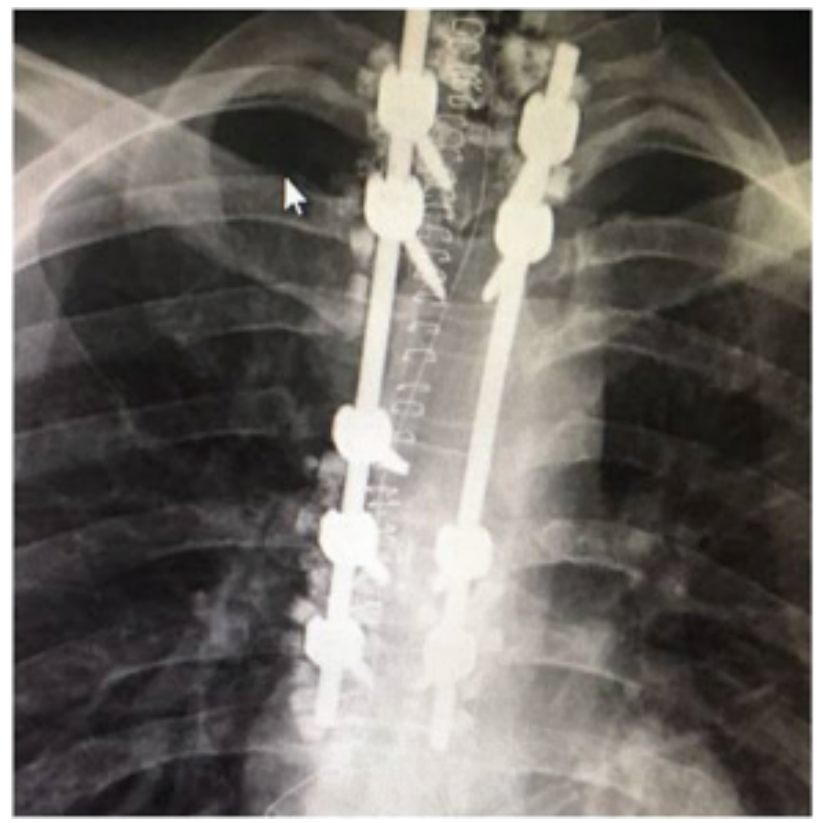

Figure 2. Anteroposterior view $\mathrm{X}$-ray of the thoracic spine showing posterior segmental instrumentation at the T2-T7 levels
(2). $A B C$ have $1-1.4 \%$ of incidence all primary bone tumors $(3,4)$. The spine is involved in $15 \%$ of the primary spine tumors. The cervical spine is affected in $30 \%$ of cases, the thoracic spine in $25-30 \%$, the lumbar spine in $30-45 \%$ and the sacrum in $13 \%$ (5). Spinal lesion usually affects vertebral body and posterior elements (lamina, peduncle, facet joints) (60\%). ABC also can affect vertebrae corpus (40\%) (1,3). Boriani et al. (6) indicated that $A B C$ had been seen in lumbar spine more often than the other spine parts. Zileli et al. (7) found that sacrum and lumbar spine has been more affected than the others. On the other hand, Papagelopoulos et al. (8) found that cervical and thoracal spine is more affected than the lumbar part of spine.

$A B C$ usually occurs approximatelyin second decade of life and rarely after 30 years of age. $A B C$ more often seen in females than males $(9,10)$. Clinical presentation is usually pain, sensory disturbance, motor weakness, kyphoscoliosis and swelling. Pain with duration between 3 months and years, frequently increases at night and on supine position. Rarely symptoms related to acute vertebral collapse with or without spinal cord injury nerve, root compression, deformity and/or instability (9). Plain radiographs are inadequate in detection of $A B C$ in early age, usually combination of plain radiography and advanced imaging techniques is necessary. Therefore, advanced imaging technique should be utilized such as MRI and computed tomography $(\mathrm{CT})$. Characteristic ballooning of the posterior elements may be shown in plain radiography (7). CT scans typically reveal a characteristic soap-bubble appearance with fluid-fluid levels, which represents a ballooning, multilocular lytic lesion and pathologic fracture or vertebral collapse $(3,11)$. The presence multiloculated cyst fluid-fluid filled levels due to presence of blood in different stages of within the cyst. Each multiloculated lobule gives different signal characteristics related to different stages lesions. MRI also shows cord and nerve root compression (12). In differential diagnose osteosarcoma, giant cell tm, chondroblastoma, fibrous dysplasia, fibrosarcoma, metastatic lesions should be recognized because these lesions also have fluid-fluid levels in advanced imaging techniques $(10,13)$. In the present case, the lesion was diagnosed $A B C$ based on typicalpattern multilocular cysts with fluid-fluid level on the MRI. The exact diagnose is biopsy. Open biopsy and frozen sections was offered to confirm diagnose (14). Biopsy confirmed the $A B C$ diagnose.

Treatment of the $A B C$ is controversial. In the literature, although there are a few reports of spontaneous $A B C$ regression, the cause of spontaneous regression is unknown. Kitamura et al. (3) claimed that $A B C$ can have spontaneous regression in elderly because elderly patients were attributable to thrombosis and fibrosis. On the other hand, in patients with neurological involvement early diagnose and treatment is should be utilized. Treatment choices are complete excision, curettage, arterial embolization, intralesional drug injections, radiation or combination of these $(7,15)$. In conditions neurological deficit and/or spinal instability surgical treatment should be utilized. For less rate of recurrence complete excision seems to 
be best choice. If also there is spinal instability, instrumented stabilization should be added. Partial excision and curettage can result in higher risk of recurrence (16).

In conditions only pain (without neurological deficit or spinal instability) arterial embolization, intralesional calcitonin or methylprednisolone injection can be treatment choice for pain relief, but carries recurrence risk (4). Calcitonin inhibits osteoclast activity and induce formation of cancellous bone. Methylprednisolone inhibits fibroblastic action and angiogenesis. But intralesional injection can be required long period to decrease symptoms (17). Arterial embolization aims to reduce vascularity. Amendola et al. (18) claimed that arterial embolization can be treatment choice for the small and less destructive lesions, also can decrease intraoperative bleeding. Radiation therapy is adjuvant therapy, not first line therapy for $A B C$. Radiation therapy should be added in conditions of partial excision or in aggressive recurrent $A B C$ or inoperable lesions, but carries risk of sarcomatous changes and irradiation myelopathy (17). The presented case $A B C$ of thoracic vertebrae was treated with surgical resection followed by vertebral fusion and instrumentation. Embolization has not been applied because of thoracic aortography showed minimal opacification. The surgical treatment concluded with no pain no neurological deficit after six months.

In conclusion $A B C$ is a rare cause of acute paraplegia. Although $A B C$ is benign bone tumor can result in expansilespontaneous hemorrhagic mass into the posterior epidural space that can cause spinal cord compression and paraplegia. Early diagnose and urgent decompression is necessary to prevent neurological complications.

\section{Ethics}

Informed Consent: Written in formed consent form was obtained.

Peer-review: Internally peer-reviewed.

\section{Authorship Contributions}

Surgical and Medical Practices: G.Ö., A.D.Ş.K., Concept: G.Ö., A.D.Ş.K., P.A., Design: G.Ö., A.D.Ş, F.Ü.O., Data Collectionor Processing: G.Ö., F.U.Ö.I.A., Analysis or Interpretation: G.Ö., F.U.Ö.,I.A., Literature Search: G.Ö., A.D.Ş.K., Writing: G.Ö., A.D.Ş.K., P.A.

Conflict of Interest: No conflict of interest was declared by the authors.
Financial Disclosure: The authors declared that this study has received no financial support.

\section{References}

1. Anchan C. Giant cell tumor of bone with secondary aneurysmal bone cyst. Int J Shoulder Surg 2008;2:68.

2. Jaffe HL, Lichtenstein L. Solitary unicameral bone cyst with emphasis on roentgen Picture, the pathologic appearance and pathogenesis. Arch Surg 1942;44:1004-25.

3. Kitamura T, Ikuta K, Senba H, Komiya N, Shidahara S. Long-term follow-up of a case of aneurysmal bone cyst in the lumbar spine. Spine J 2013;13:55-8.

4. Cugati G, Pande A, Jain PK, Symss NP, Ramamurthi R, Vasudevan $\mathrm{CM}$. Aneurysmal bone cyst of the lumbar spine. Asian J Neurosurg 2015;10:216-8.

5. Burch S, Hu S, Berven S. Aneurysmal bone cysts of the spine. Neurosurg Clin N Am 2008;19:41-7.

6. Boriani S, De lure F, Campanacci L Gasbarrini A, Bandiera S, Biagini $R$, et al. Aneurysmal bone cyst of the mobile spine: report on 41 cases. Spine 2001;1:27-35.

7. Zileli M, Isik HS, Ogut FE, Is M, Cagli S, Calli C. Aneurysmal bone cysts of the spine. Eur Spine J 2013;22:593-601.

8. Papagelopoulos PJ, Currier BL, Shaughnessy WJ, Sim FH, Ebsersold MJ, Bond JR, et al. Aneurysmal bone cyst of the spine. Management and outcome. Spine 1998;23:621-8.

9. Mathur S, Aswani Y, Sankhe SS, Hira PR. Aneurysmal bone cyst of thoracic spine mimicking spinal tuberculosis. J Craniovertebr Junction Spine 2011;2:99-101.

10. DiCaprio MR, Murphy MJ, Camp RL. Aneurysmal bone cyst of the spine with familial incidence. Spine 2000;25:1589-92.

11. Patnaik S, Jyotsnaran Y, Uppin SG, Susarla R. Imaging features of primary tumors of the spine: A pictorial essay. Indian J Radiol Imaging 2016;26:279-89.

12. Chan MS, Won YC, Yuen MK, Lam D. Spinal aneurysmal bone cyst causing acute cord compression without vertebral collapse: CT and MRI findings. Pediatr Radiol 2002;32:601-4.

13. Meyers SP. MRI of bone and soft tissue tumors and tumorlike lesions, differential diagnosis and atlas. Radiology 2009;250:353.

14. Singh DK, Singh N, Pant MC. Aneurysmal bone cyst: An unusual presentation of back pain. Asian J Neurosurg 2014;9:105-7.

15. Brembilla C, Lanterna LA, Bosisio M, Gritti P, Risso A, Signorelli $A$, et al. Spontaneous regression after extensive recurrence of a pediatric cervical spine aneurysmal bone cyst. Case Rep Oncol Med 2014;9:1-6.

16. Liu JK, Brockmeyer DL, Dailey AT, Schmidt MH. Surgical management of aneurysmal bone cysts of the spine. Neurosurg Focus 2003;15:4

17. Cugati G, Pande A, Jain PK, Symss NP, Ramamurthi R, Vasudevan $\mathrm{CM}$. Aneurysmal bone cyst of the lumbar spine. Asian J Neurosurg 2015;10:216-8.

18. Amendola L, Simonetti L, Simoes CE, Bandiera S, De lure F, Boriani S. Aneurysmal bone cyst of the mobile spine: the therapeutic role of embolization. Eur Spine J 2013;22:533-41. 